\title{
$5 \mathrm{~W} 1 \mathrm{H}$ 情報抽出・分類によるテキスト要約
}

\author{
奥村 明俊 ${ }^{\dagger}$ 池田 崇博 ${ }^{\dagger}$ 村木 一 至计 \\ オフィス業務においては, 大量の関連情報から, 特定のイベントについての経過や状 \\ 況を把握するために，要約や抄録の生成が求めらている。本論文では，複数の文書か \\ ら抄録や要約をロバストに生成する手法として，あるイベントに関する時間的経緯を \\ 抄録として生成するエピソード抄録と，大量の情報を大局的に把握するための要約文 \\ を生成する鳥瞰要約を提案する。エピソード抄録では，あるイベントを表す $5 \mathrm{~W} 1 \mathrm{H}$ \\ (だれが，なにを，いつ，どこで，どうした）が含まれる文書を検索し，そのイベント \\ に関する時間的経緯を抄録として生成する。鳥瞰要約は, 文章中の $5 \mathrm{~W} 1 \mathrm{H}$ 要素を，シ \\ ソーラスを用いてそれらの上位概念で置き換えることで, 要約文を生成する。新聞記 \\ 事 10,000 件とセールスレポート 2,500 件を対象として適用し, その効果を確認した。 \\ キーワード： 抄録, 要約, エピソード, 鳥瞰, $5 W 1 H$

\section{Text Summarization based on Information Extraction and Categorization Using 5W1H}

\author{
Akitoshi OKumura ${ }^{\dagger}$, Takahiro IKeda ${ }^{\dagger}$ and KaZUnori Muraki ${ }^{\dagger}$
}

In an office, it is necessary for understanding the temporal transition and the overall situation on an event from various information to extract and abstract a large number of documents. This paper proposes two robust methods for generating an extract and an abstract from documents: an episodic extraction method which generates an extract on the temporal transition of an event and an overall abstraction method which generates an abstract of overall documents for survey. The episodic extraction method retrieves documents including the $5 \mathrm{~W} 1 \mathrm{H}$ (who, when, where, what, why, how and predicates) information which specifies an event and generates an extract on the temporal transition of the event. The overall abstraction method abstracts documents by replacing $5 \mathrm{~W} 1 \mathrm{H}$ elements in each document with their upper categories in a thesaurus. These methods proved to be effective for office work from an application to 10000 news articles and 2500 sales reports.

KeyWords: extract, abstract, episode, survey, $5 \mathrm{~W} 1 \mathrm{H}$

\section{1 はじめに}

インターネット，イントラネットが急速に拡大し，情報洪水と呼ばれる程，多くの情報が氾 濫している，氾監する情報を効率良く入手する技術として，従来から，要約や抄録に関する研究

†日本電気 (株) C\&Cメディア研究所, NEC Corp., C\&C Media Research Laboratories

†† 日本電気 (株) パーソナルソフトウエア事業部, NEC Corp., Personal Software Diviosn 
が行なわれている (田村, 田村 1992; 原, 水谷, 江里口 1994; 山本, 増山, 内藤 1995). これらの 多くは，主に一つのドキュメントの内容を要約することに重点を置いているため, 新聞やニュー スのようなイベントに対して複数のドキュメントが存在する場合, 時間的なイベントの変化の ようなエピソード的な情報を構造化しにくいという問題がある (吉田, 徳永, 田中 1996). 情報 を構造化して要約する手法としては，ドキュメントに対する重要項目をテンプレートとして準 備し，テンプレートを用いて抽出しな情報から要約を行なう手法がある (McKeown and Radev 1995; 安藤, 土井 1994). また，要約のためのテンプレートを，与えられた話題に関するドキュ メント集合から自動的に抽出する手法も提案され, 重要度を考慮したテンプレートの抽出が可 能となっている (吉田他 1996).

実際のオフィス業務においては，イベントの経過情報や状況把握など分析的な情報選別のた めに，要約や抄録情報が求められる。この場合，ユーザの関心や意困が多岐に渡り，かつ，対 象とする関連情報が大量に存在する，そのため，重要度を考慮するだけでなく，ユーザの様々 な視点や観点から抄録情報をロバストに生成するフレームワークと，大量にある情報を大局的 に把握するための要約が必要となる.

一般に, 要約 (Abstract) とは, 文書の中心的な話題を簡潔にまとめたものであり, 抄録 (Extract) とは文書から何らかの基準で文を抜き出しだしたものである.要約は，(1) indicative: 読むか読まないか (2) informative: 内容の要約 (3) critical: 要約十批評 (4) comparative: サー ベイというレベルに分けることができるが, 内容の理解が必要となり, 現在の技術では困難な ものが多い (Paice 1990).

抄録は，何らかの手かがりを元に重要な文を抜き出すことで，各文にスコアを付けてスコア の高いものを抜き出すことが多い. 手法としては，キーワードの頻度によるもの，タイトルの キーワードを用いるもの，文の位置情報を用いるもの，構文関係を用いるもの，手がかりとな るキーワードを用いるもの, 文の関係に着目するもの, などの方法が提案されている. エピ ソード抄録は，係り受け関係と固有名詞やパターン表現を手がかりとして，情報の要素をより 詳細にインデクスして，時間的または位置的に情報をアレンジして抄録を作成する手法である.

本稿では, 時間表現, 固有名詞, 動作表現, 動詞の格フレームに着目して, テキストに含ま

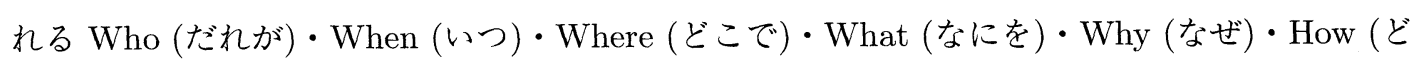
のように)・Predicate(どうした) といういわゆる $5 \mathrm{~W} 1 \mathrm{H}$ 情報を抽出して, 時間や場所をソート キーとしたエピソード抄録， $5 \mathrm{~W} 1 \mathrm{H}$ 項目にシソーラスを適用して上位概念で要約する鳥瞰要約 を提案する. $5 \mathrm{~W} 1 \mathrm{H}$ 情報は, 日常の出来事を理解するためのキーとなっている概念であり, 出 来事の内容の核心部分を表現する。 $5 \mathrm{~W} 1 \mathrm{H}$ 情報に着目することによって，オフィス業務におけ る有効な抄録情報と大局情報を要約として生成することが可能となる.

本報告では，まず，オフィス業務で求められる抄録と要約について説明し，次に，5W1H 情 報を用いたエピソード抄録と鳥瞰要約について説明する。そして， $5 \mathrm{~W} 1 \mathrm{H}$ 情報抽出の手法につ 
いて述べ，エピソード抄録を新聞記事とセールスレポートに適用した事例と，鳥瞰要約を新聞 記事情報に適用した事例を報告する。

\section{2 オフィス業務で求められる要約・抄録}

ユーザの情報要求 (information need) には，ユーザの情報に対する認識や理解度によって 異なるレベルの要求が存在する (Taylor 1968). ユーザが，ある情報の集合に対して，まったく 情報がなければ，そもそも，その情報の集合は何を話題としたものかといった大局的な情報把 握の要求が生じるであろうし, 情報要求がある程度具現化されていていれば，その情報をトリ ガーとして, 詳細情報や関連情報に対する要求が生じる. 最近の WWW やインターネットの発 達によって, オフィス業務においては, まさに, 異なるレベルの情報要求が進化的に変遷する 状況が生じている (Bates 1989)。例えば，インターネットやフィルタリングサービスなどを通 じて，大量の情報が提供されているが，提供された情報および情報の集合に対して，以下の 3 種類の情報要求が存在する.

\section{鳥瞰情報: 情報全体像の把握}

提供された情報が数量的に膨大な場合，全体像を鳥瞰的に把握する必要がある．例えば，製 品開発情報の集合が得られた場合, いつ頃，どのような種類の組織が，どの分野に関して，何 を発表しているのかといった集合全体を把握したいという情報要求がある.

\section{時間的経緯: 縦方向への展開}

提供された情報に含まれるイベントが，発生するに至る経緯情報が必要となる，例えば，「A 社が〜ギがのメモリを開発した」という 1 次情報に対して, A 社が今までメモリの開発に関し てどのような時期にどのような技術を開発してきたのかという，いわば，1 次情報からの垂直 方向, 縦方向への情報要求がある.

\section{類似情報: 横方向への展開}

提供された情報を構成する要素を变数として，類似情報を比較的に獲得する．例えば，技術 調査レポートを作成するユーザが，新聞記事検索を行なって，「A 社が低価格の X 製品を開発し た」という情報を検索した場合，詳細情報は新聞記事本文で得ることができる，さらに，「他社 はどうなっているか」,「A 社の $\mathrm{Y}$ 製品はどうなっているか」などの情報を得るため 2 次的検索 として行なう。いわば， 1 次情報からの水平方向，横方向への情報要求がある.

現状の情報検索技術は，これらの情報要求に対して必ずしも有効な手段を提供していない. 現在，一般的に行なわれている複数のキーワードの組み合わせによる情報検索では，キーワー ドが存在すれば，その論理的関連性の有無に係わらず文書が検索されノイズとなることが多い. 例えば，NEC\&半導体\&生産というキーワードで新聞記事を検索すると,「NEC が〜と技術提

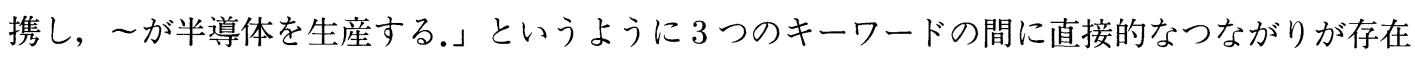
しない文も検索されることになる。このようなノイズは，いわゆる係り受け検索によって有効 


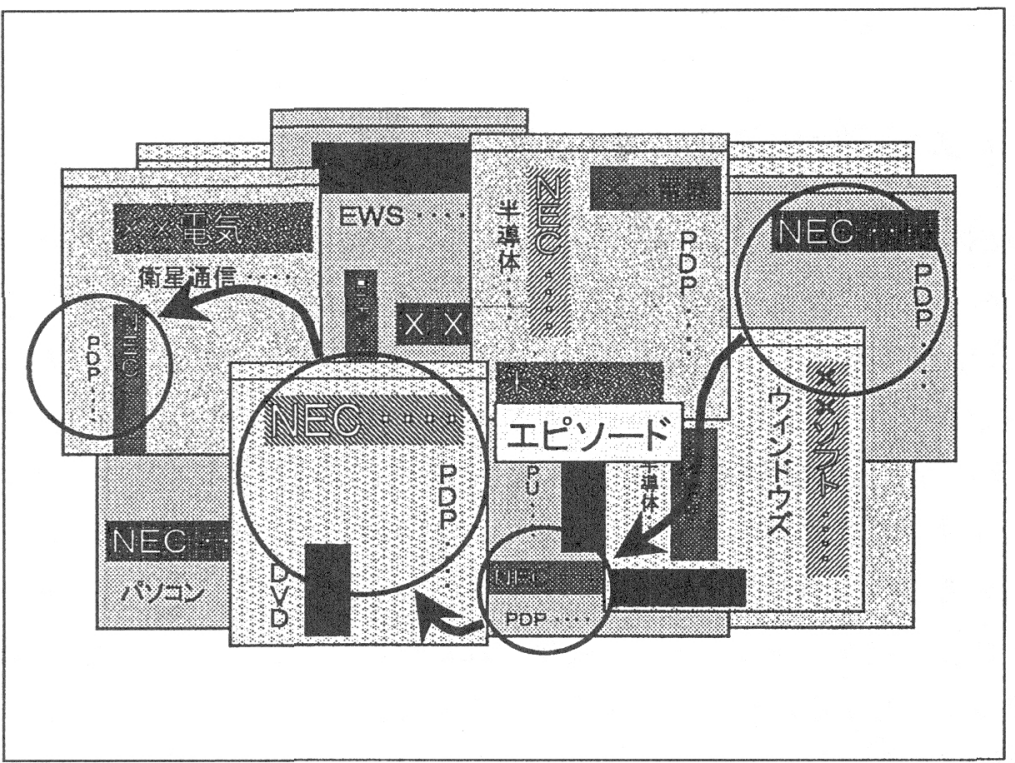

図 1 エピソードの拾い読み

に絞り込まれることが報告されている(Mine, Aso, and Amamiya 1997).

我々は，これらの問題点を解決するために，係り受け情報だけでなく，テキストに含まれる Who (だれが)・When (いつ)・Where (どこで)・What (なにを)・Why (なぜ)・How (どのよ うに)・Predicate(どうした) といういわゆる $5 \mathrm{~W} 1 \mathrm{H}$ 情報を用いた分類・ナビゲーション手法を 提案してきた(池田，奥村，村木 1997; Ikeda, Okumura, and Muraki 1998)。次章では，時間的 経緯と鳥瞰情報に関する情報要求に応えるために開発した，5W1H 情報を用いたエピソード抄 録と鳥瞰要約について述べる。

\section{3 エピソード抄録・鳥瞰要約}

\section{1 エピソード抄録}

情報の中から特定のイベントに着目し，そのイベントの時間的な経過をエピソードのよ うに読める形の抄録として提示する。例えば，図1のような電機業界に関する技術情報情報が 与えられた時に，NECのPDPに関する取り組みという観点で，情報を時間的な経過とともに 拾い読みすることができれば，一連のエピソードのように情報を獲得することができる。

この場合，単純な論理式によるキーワード検索では，関連性の低いものも混在してエピソー ドのように読みとれなくなってしまう。そこで，図 2 のように，情報の中から $5 \mathrm{~W} 1 \mathrm{H}$ 情報を抽 


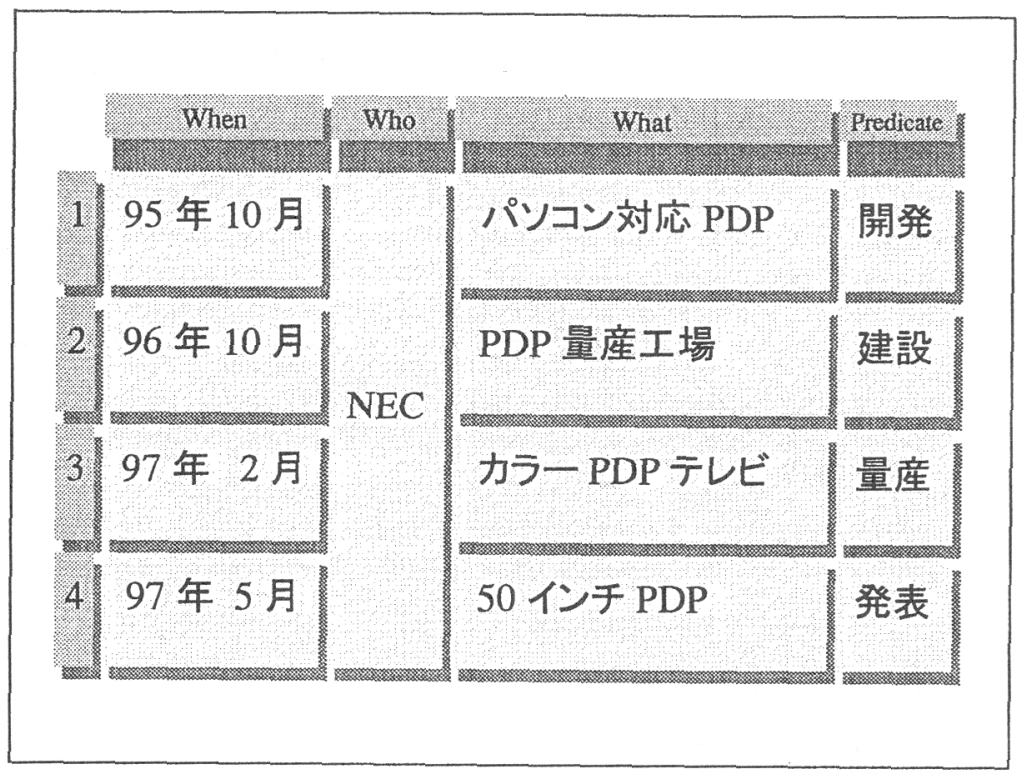

図 2 エピソード抽出

出して, ある出来事に関して, predicate と argument の関連のある情報だけを抽出し，時間順 に並べて抄録情報を生成する。

この結果，その出来事に関するこれまでの経緯をエピソード的に読むことができるようにな る。例えば，Who 要素に NEC，What 要素にPDP を含む文書を検索し，時間と対応づけて順 に並べることで，NECのPDPの開発に関するエピソードとして,「95 年 10 月に NECがパソコ ン対応 PDP 開発。9 96 年 10 月に NEC がPDP 量産工場を建設。97 年 2 月に NECがカラー PDP テレビを量産. 97 年 5 月に NEC が50 インチ PDP を発表。」という抄録を生成すること が可能となる。

エピソード抄録としては，時間軸とともに場所に着目することによって，位置的に展開した エピソードを提示することが可能である。罒3は，技術関連ニュースヘッドラインから，Where 要素として場所の名前を抽出し, 地四上にマップして表示した例である。対応する場所にマップ して表示することで，エピソードと場所との関連を視覚的にとらえることが可能となる。エピ ソードの位置展開は, 特に, 政治家の遊説, 犯人の逃亡記事, 台風など自然災害情報のように, 移動を伴うイベントのエピソード抄録として有効だと思われる。しかしながら，文中の Where 要素が, 必ずしもイベントの発生地点を表しているのではないため, Where 要素を含むすべて の文を，同等に地図上にマップすべきかどうかは議論の余地がある。例えば，「北海道に製品工 場を建設」と「北海道向け製品工場を建設」とでは, Where 要素「北海道」が表している事柄 が異なっている。このような場合の位置情報の効果的な提示方法については，今後も検討が必 


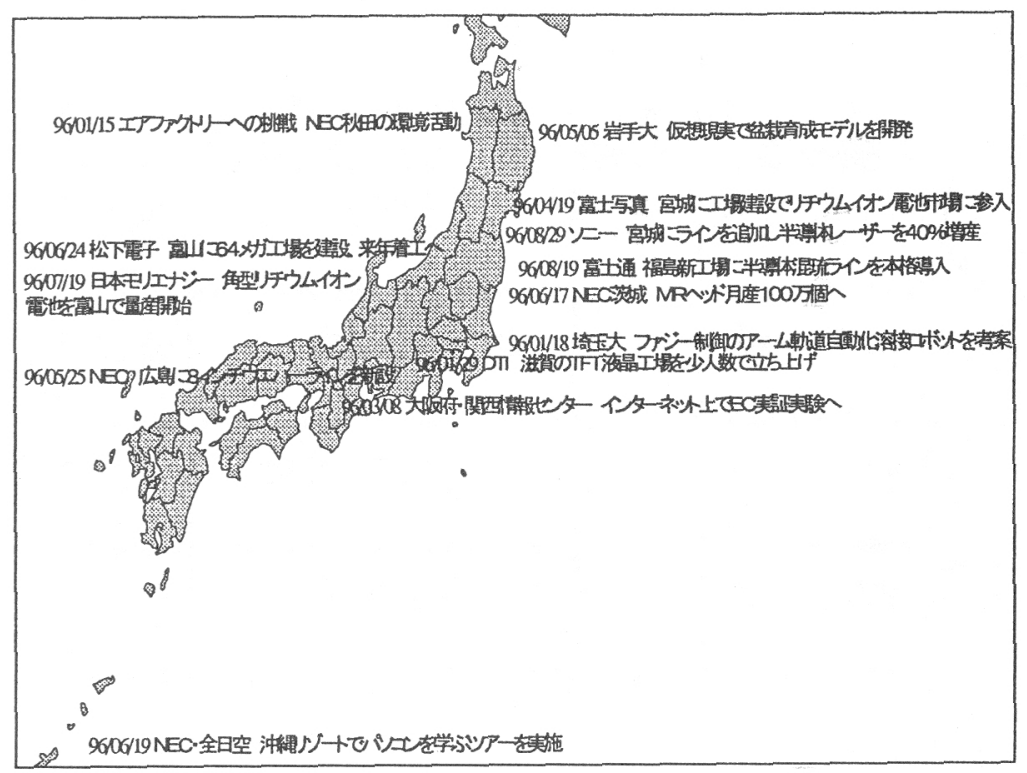

図 3 エピソードの位置展開

要である。

\section{2 鳥瞰要約}

$5 \mathrm{~W} 1 \mathrm{H}$ 抽出した情報の集合に対して，シソーラスを用いることによって，各要素の情報をそ れらの上位概念で代表させて，鳥瞰的に要約を生成することが可能となる。図 4 は, 「NECが PC98NX を発売」「メX通信機が次世代パソコンを開発」「メX電気が携帯パソコンを発壳」「メ

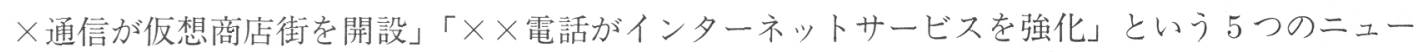
スから Who 要素とWhat 要素を抽出し, それぞれの要素に対してシソーラスの上位概念を照 合したものである。

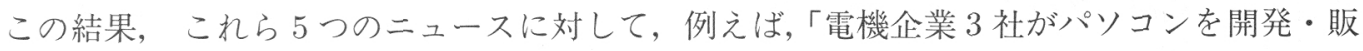
売した。」あるいは,「通信企業 2 社がネットワークサービスを開設・強化した。」という鳥瞰的な 要約を生成することができる。

鳥瞰要約に対しては，要約の対象となる母集団の情報に対して要約率と要約レべルを定義す ることができる。まず，ある1つの 5W1H 要素wh (Who, When, Where, What, Why, How, Predicateのどれか) に対して抽出された単語の集合 $\mathbf{W}_{w h}$ をある概念 $C_{w h}$ で代表させるとき の要約率 $R_{w h}$ を，以下のように定義する。

$$
R_{w h}=\frac{\operatorname{Num}\left(\mathbf{W}_{w h} \cap \operatorname{Word}\left(C_{w h}\right)\right)}{\operatorname{Num}\left(\mathbf{W}_{w h}\right)}
$$




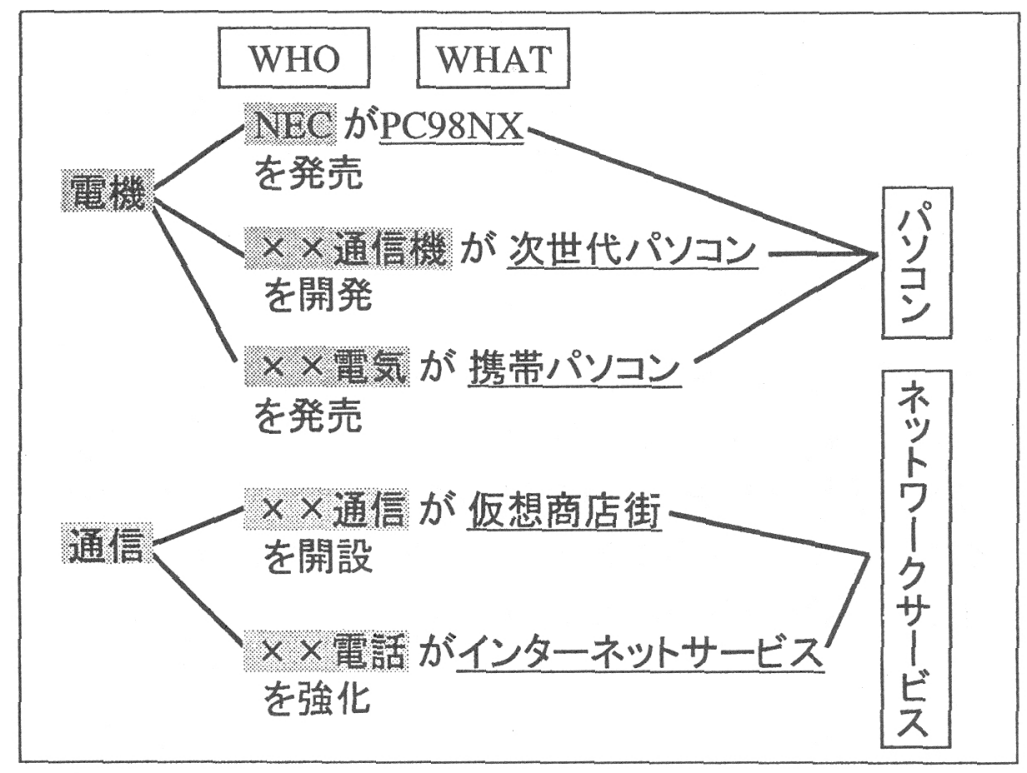

図 4 鳥瞰要約

ただし，

$$
\begin{aligned}
& \operatorname{Num}(S) \text { : 集合 } S \text { の要素数 } \\
& \operatorname{Word}(C) \text { : 概念 } C \text { に含まれるすべての単語の集合 }
\end{aligned}
$$

とする。このとき，全体の要約率 $R_{\text {all }}$ を，

$$
R_{\text {all }}=\prod_{w h \in\{5 \mathrm{~W} 1 \mathrm{H} \text { 要素 }\}} R_{w h}
$$

と定義する。これは，各 $5 \mathrm{~W} 1 \mathrm{H}$ 要素を構成する単語のうち，それらを置き換える上位概念に 含まれるものの割合を，すべての $5 \mathrm{~W} 1 \mathrm{H}$ 要素に関して乗じたものとなっている。例えば，困 4 の 5 つの文について, Who 要素を「電機企業」で代表させ, What 要素を「パソコン」で 代表させ, Predicate 要素を「発売」で代表させる場合, 各 $5 \mathrm{~W} 1 \mathrm{H}$ 要素に対する要約率は, $R_{W h o}=0.6, R_{\text {What }}=0.6, R_{\text {Predicate }}=0.4$ となり, 全体の要約率は, $R_{\text {all }}=0.144$ となる.

要約レベルは， $5 \mathrm{~W} 1 \mathrm{H}$ 要素のそれぞれについて，独立に定義される值で，置き換える上位概 念が，シソーラス上で何レベル上位の概念であるかを示す。要約レベルをあげていくと要約率 は高いものとなる。例えば，日本の各分野の 100 社が，様々な製品を開発したニュースが 100 件与えられた場合,「日本企業 100 社が製品を開発した。」という要約文は，要約率 $100 \%$ という ことになる。しかしながら，このような要絇文が，ユーザにとって価値があるとは言いにくい。 要約率・要約レベルという概念を導入することで，ユーザが指示する要約率・要約レベルに合 わせるようにシソーラスの上位概念を探索して，鳥瞰要約を生成することが可能となっている。 
実際の要約では, 適切な要約率になる上位概念を選択できないことがあるが, シソーラスで適 切にカバーできない要素に関しては, 頻度の多かった代表的なものを列挙して「など」という 表現を加えて代表させることで，上位概念の代わりに用いることで解決できる.

\section{$3.35 \mathrm{~W} 1 \mathrm{H}$ 要素の抽出}

$5 \mathrm{~W} 1 \mathrm{H}$ 要素の抽出は, 形態素解析結果と辞書情報を基にした浅い解析手法, 表層格指向パー シング CBSP (Case-Based Shallow Parsing) によって行なう.CBSPによって, 頑健で効率的 な $5 \mathrm{~W} 1 \mathrm{H}$ 抽出が実現できる. CBSP は, 形態素解析を行い各単語に品詞情報を付与したテキス トに対し, 語菓情報, 字句のパターン, 助詞の情報を用いて $5 \mathrm{~W} 1 \mathrm{H}$ 解析を行うモデルで, 浅い 解析により, 頑健で効率的な解析を実現している. 基本的には, 以下の 3 ステップから構成さ れる。

固有名詞の抽出

固有名詞のうち, 人名・組織名をWho 要素として, 地名はWhere 要素として抽出す る.これにより, 例えば,「NECが中国で半導体を生産する.」という文からは, Who 要素として NECが, Where 要素として中国が抽出される. 現在, 約 6 万語の固有名 詞辞書を利用している。

特徵的表現のパターンマッチ

特徵的なパターンに着目して，人名・組織名（Who 要素），日時（When 要素）を抽 出する，例えば，「株式会社 $\times \times 」, 「 \times \times$ 大学」などのように「株式会社」が頭に付く 語や大学が後に続く語は, 会社名や大学名と考えられるため, これらを Who 要素と

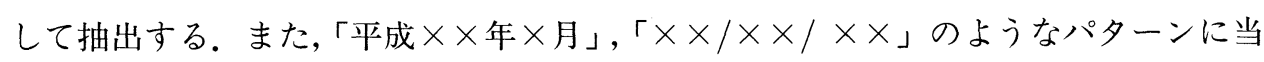
てはまる語は日時を示していると考えられるため, これらは When 要素として抽出す る. 現在, 人名・組織名のパターンを約 100 種類, 日時のパターンを約 20 種類用意 して, 解析に利用している.

(3) 表層格解析

上記 $1 ， 2$ のステップで抽出されなかった名詞は，その名詞に続く助詞等の情報を基 に, どの $5 \mathrm{~W} 1 \mathrm{H}$ 要素に対応するのかを決定する．例えば,「が」および「は」が後に 続く語はWho 要素とし,「を」および「に」が後に続く語はWhat 要素とする．動詞 は Predicate 要素として抽出する.

1 文中に複数の Predicate 要素がある場合には, 他の $5 \mathrm{~W} 1 \mathrm{H}$ 要素が, もっとも近い Predicate 要素に係るものとして処理する，ただし，このとき，同種の $5 \mathrm{~W} 1 \mathrm{H}$ 要素 は，同じ Predicate 要素には係らないものとしている.

詳細なアルゴリズムを困 5 に示す. 


\section{procedure CBSP;}

\section{begin}

入力文を形態素解析;

foreach 文中の単語 do begin

if その単語が人名または組織名である then

その単語を Who 要素としてマークし，スタックに積む;

else if その単語が地名である then

その単語を Where 要素としてマークし，スタックに積む;

else if その単語が人名・組織名のパターンに適合する then

その単語を Who 要素としてマークし，スタックに積む;

else if その単語が日時のパターンに適合する then

その単語を Where 要素としてマークし，スタックに積む;

else if その単語が名詞である then

$$
\text { if その次の語が「が」または「は」である then }
$$

その単語と, 未定の要素をWho 要素としてマークし，スタックに積む;

if その次の語が「を」または「に」である then

その単語と, 未定の要素を What 要素としてマークし，スタックに積む;

else

その単語を, 未定の要素として保持する;

else if その単語が動詞である then begin

その単語を $5 \mathrm{~W} 1 \mathrm{H}$ セットの Predicate 要素として確定する;

repeat

スタックから 1 語取り出す;

if その単語に付けられたマークと同じ種類の $5 \mathrm{~W} 1 \mathrm{H}$ 要素がまだ未確定である then その単語を付けられたマークと同じ種類の $5 \mathrm{~W} 1 \mathrm{H}$ 要素として確定する;

else

repeat ループを脱出する;

until スタックが空である;

end

end

end

図 5 The algorithm for CBSP 
表 1 Who, What, Predicateの各要素および全体での抽出結果の評価

\begin{tabular}{lrrrrrrrrrr}
\hline & \multicolumn{1}{l}{ Who 要素 } & \multicolumn{3}{c}{ What 要素 } & \multicolumn{4}{c}{ Predicate 要素 } & \multirow{2}{*}{ 存在 } \\
\cline { 2 - 9 } & 非存在 & 計 & 存在 & 非存在 & 計 & 存在 & 非存在 & 計 & 全体 \\
\hline 正解 & 5423 & 71 & 5494 & 5653 & 50 & 5703 & 6042 & 5 & 6047 & 5270 \\
誤り & 414 & 490 & 904 & 681 & 14 & 695 & 55 & 296 & 351 & 1128 \\
\hline 合計 & 5837 & 561 & 6398 & 6334 & 64 & 6398 & 6097 & 301 & 6398 & 6396 \\
\hline 精度 & $92.9 \%$ & $12.7 \%$ & $85.9 \%$ & $89.2 \%$ & $78.1 \%$ & $89.1 \%$ & $99.1 \%$ & $1.7 \%$ & $94.5 \%$ & $82.4 \%$ \\
\hline
\end{tabular}

CBSPによる解析で，約 6400 件の新聞記事へッドラインから，実際にWho, What, Predicate 要素を抽出した結果について分析した結果を表 1 に示す.

この表では, 新聞記事へッドラインにおいて, Who, What, Predicateの各要素が実際に存 在している場合と存在していない場合のそれぞれについて，それらの要素が正しく抽出された文 の数と正しく抽出されなかった文の数をまとめている。 これによると, Who, What, Predicate の各要素が実際に存在している場合には，ほぼ $90 \%$ 以上の文から各要素が正しく抽出できてい る。しかしながら, 各要素が実際に存在していない場合には, 高い精度が得られていない.これ は, 要素が実際に存在していない場合でも, 別な語をその要素として抽出してしまう傾向があ るためである。これにより，関係のない語が $5 \mathrm{~W} 1 \mathrm{H}$ 要素として抽出されることになるが，正し い $5 \mathrm{~W} 1 \mathrm{H}$ 要素が落ちるわけではないので， $5 \mathrm{~W} 1 \mathrm{H}$ を利用した検索において適合率を下げること はなく，実際には，大きな問題とはならない，要素がある場合とない場合との平均では，85\%か ら $95 \%$ の精度となっており，全体でも $82.4 \%$ の精度が得られている。その結果，エピソード抄 録や鳥瞰要約として，ほぼ妥当な結果を得ることができる.

\section{4 新聞記事とセールスレポートへの適用}

新聞記事 10000 件を対象として，5W1H に基づいて分類ナビゲーションを行なう情報活用 プラットフォームを構築してきた (奥村, 池田, 村木 1997). 図 6は, 構築したプラットフォーム の構成図である．指定された情報源から情報収集ロボットによって情報が収集され情報 DB に 毎日格納されていく. $5 \mathrm{~W} 1 \mathrm{H}$ 情報抽出モジュールは, 収集した情報から, 3.3 節のアルゴリズ ムにより，1 文ごとに $5 \mathrm{~W} 1 \mathrm{H}$ 情報を抽出し， $5 \mathrm{~W} 1 \mathrm{H}$ インデクスを生成する。ここでは，新聞記 事へッドラインと本文記事から Who・What・Predicate の 3 種類について, $5 \mathrm{~W} 1 \mathrm{H}$ 要素として キーワードを抽出し， $5 \mathrm{~W} 1 \mathrm{H}$ の種類とキーワードから文書を引くための $5 \mathrm{~W} 1 \mathrm{H}$ インデックスを 作成している，抽出したキーワードをそのまま用いるため，同義語は別の語として扱うことに なるが，要約文の生成時には，シソーラスによって同義語が統合されるままた，すべての文を 対象として抽出を行うため, Who, What, Predicate の 3 要素の一部が存在しない文でも, 存 在する要素からの検索が可能である. 


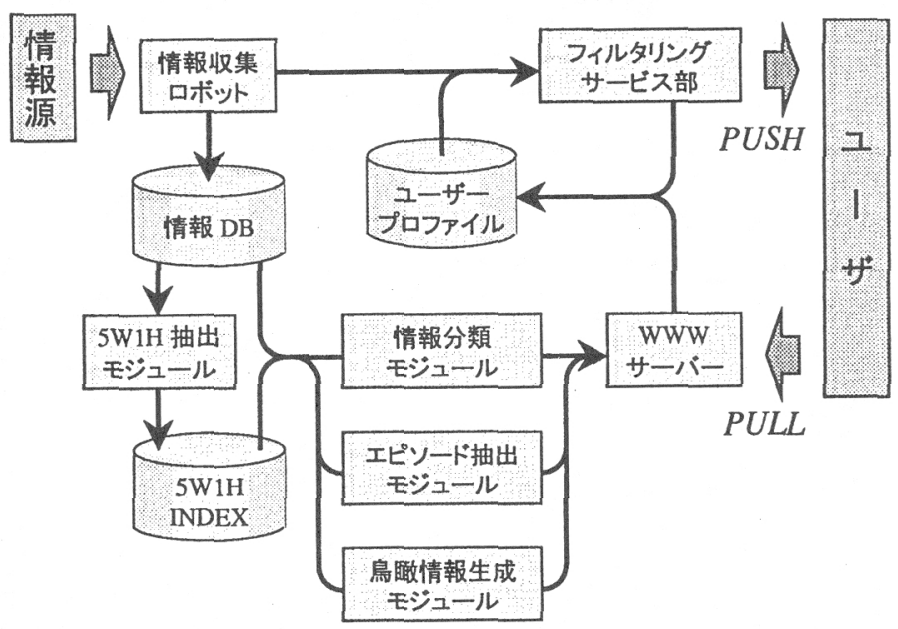

図 6 情報活用プラットフォーム

$5 \mathrm{~W} 1 \mathrm{H}$ インデクス情報を基に，情報分類モジュール，エピソード抽出モジュール，鳥瞰情報 生成モジュールが，WWW サーバーを介してユーザに分類・ナビゲーション機能を提供する。 フィルタリングサービス部は，ユーザプロファイルを参照して情報収集ロボットによって集め られた情報からフィルタリングしてユーザに配信する。ユーザは配信された情報から，5W1H 分類・ナビゲーションによって自分の読み進みたい方向へと情報を獲得していくことができる. 今回，エピソード抽出モジュールにエピソード抄録生成機能を，鳥瞰情報生成モジュールに鳥 瞰要約を生成する機能を実装した。

\section{1 新聞記事に対するエピソード抄録}

エピソード抽出では，指定されたへッドラインから Who・What・Predicate 要素を抽出し， それと同じ Who・What・Predicate 要素の組を記事中に含む文書を関連エピソードとして検索 して，へッドラインを時間順に並べて抄録として生成する。眓 7は, 「 $\mathrm{NEC}$ 半導体部門の生産予 測を $18 \%$ 増と発表」というへッドラインから抽出した $5 \mathrm{~W} 1 \mathrm{H}$ 要素のうち， NEC・半導体・生産 という Who・What・Predicate 要素を本文中にもつ記事を検索し，ヘッドラインを時間順に整 理してエピソード抄録として提示した例である。利用者は，エピソード抄録を読むことで，96 年 10 月は NECの半導体生産が下方修正され，半導体各社が投資を減らし，世界規模で市場が 減となり，12月には他の会社が工場建設を中止するなど，市場が冷え込んでいくが，97 年にな ると，次世代 DRAM で好転して，各社，計画を増額していくエピソードを読みとることがで 


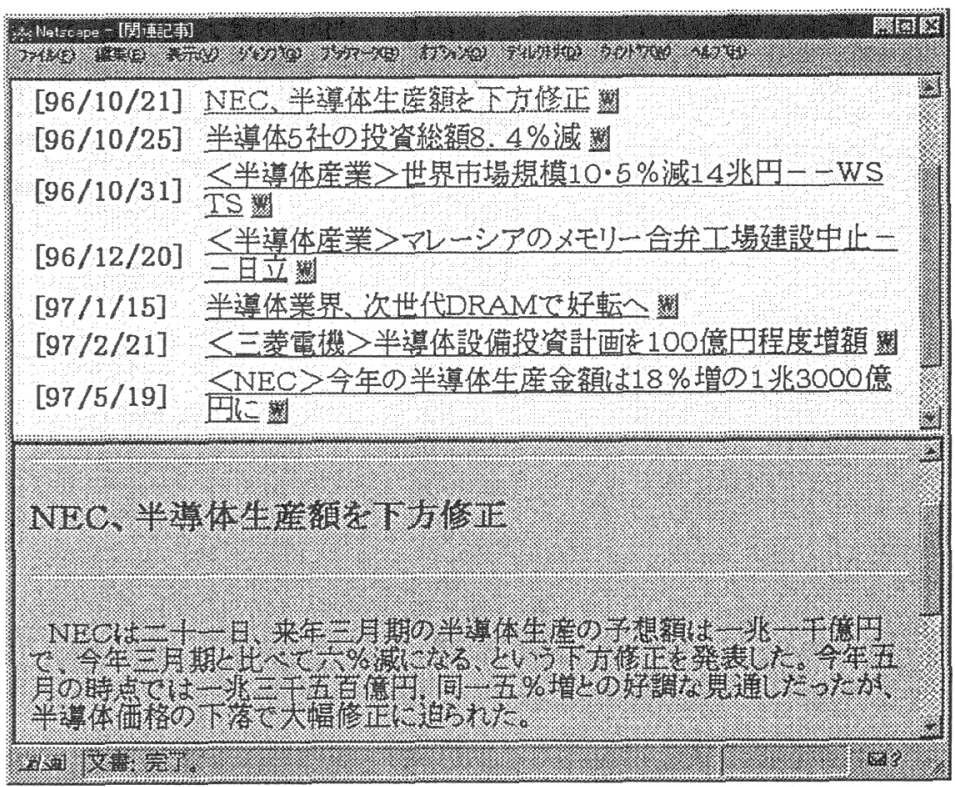

図 7 5W1H によるエピソード抽出

き， NECの半導体の生産が $18 \%$ 増に至るまでの経緯を知ることができる.

\section{2 新聞記事に対する鳥瞰要約}

情報鳥瞰では，Who 要素に出現する約 2800 の企業を業種別に分類したシソーラスと, What 要素に出現する約 2000 のキーワードを技術分野別に分類したシソーラスを利用して, Who・ What 要素の各キーワードを統合し，鳥瞰的な分類を生成する。Predicate 要素については, キーワードの種類が少ないことから，高頻度で出現するキーワード 8 語で分類している. 図 8 に 97 年 4 月の約 400 件のヘッドラインに対する情報鳥瞰の結果を示す. Who・What 要素のキー ワードを階層的なシソーラス構造として扱うことで，最初は荒い分類を提示し，必要な部分だ け展開して細かい分類を見せることができる(図 9)。

これらの鳥瞰分類結果をもとに，各月の記事の鳥瞰要約を生成する。まず，もっとも要約率 の高い要約を生成する部分，すなわち，分類された記事がもっとも多い部分について，Who， What, Predicate のシソーラス上の概念または代表的なキーワードをパターンに当てはめて要 約文を生成し，ユーザに提示する。図 80 例では,「97 年 4 月は，電機企業 30 社がマルチメディ ア総合技術に関する開発・発売などを 131 件発表している。」という要約文が生成される。この 場合, Who 要素とWhat 要素については, キーワードをシソーラス上の 1 つの上位概念で 置き換えているため, 要約レベルは 1 となり, Predicate要素については, キーワードそのまま の表現を用いているため, 要約レベルは０となる。ユーザには, この後, 要約率の高い順に要 


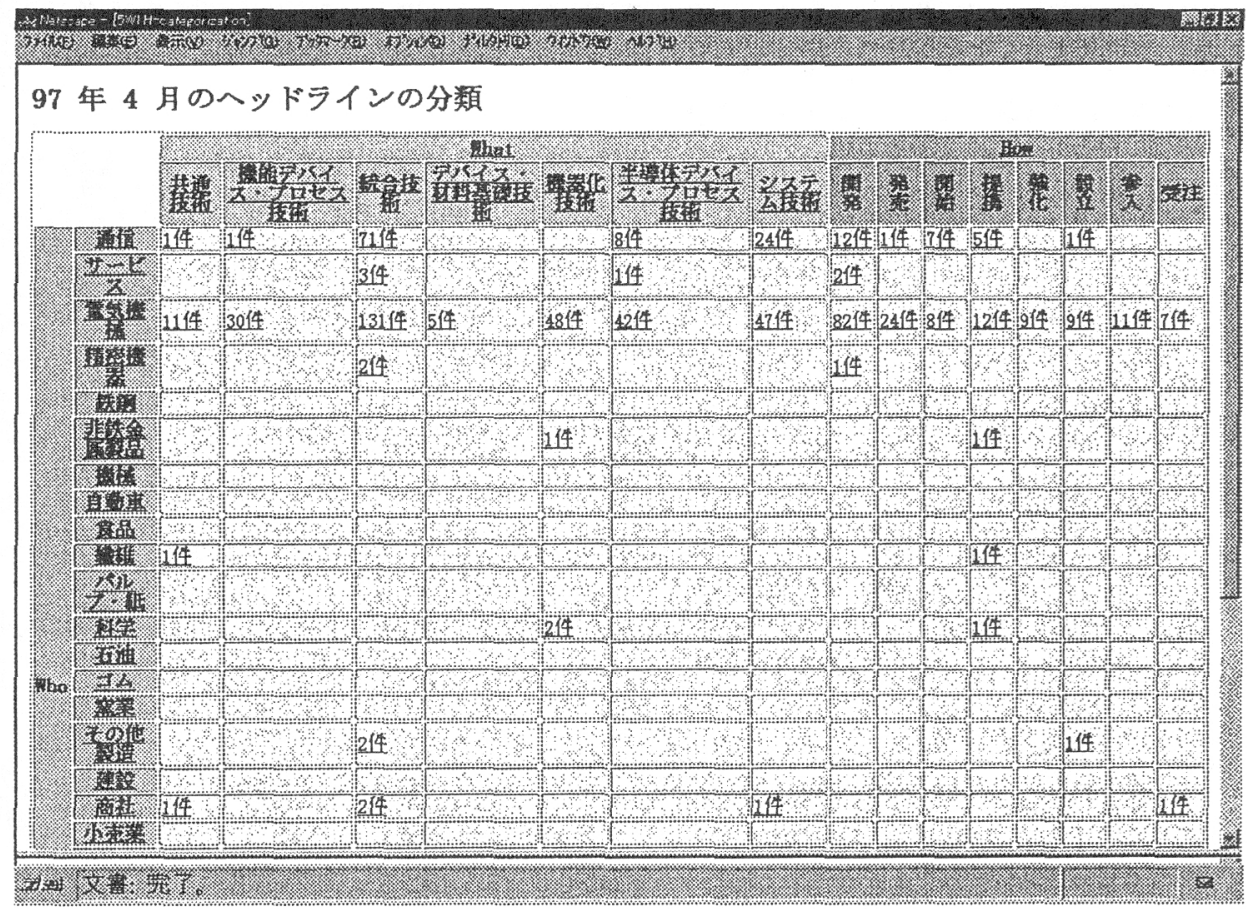

図 8 シソーラスを利用した情報鳥瞰

約文が順々に提示される。

\section{3 セールスレポートに対するエピソード抄録}

ある会社の約 2500 件のセールスレポートに対して $5 \mathrm{~W} 1 \mathrm{H}$ 情報抽出を行ない，エピソード抄 録を生成した。ここでは，実際のセールスレポートを実験用に変換した例を用いて説明する。 セールスレポートは，営業マンが担当する顧客の要望などを報告したものである。このレポー トは，メッセージアベニューという配信サービスとして関係者に配信される。セールスレポー 卜は， $5 \mathrm{~W} 1 \mathrm{H}$ 情報抽出によって，日時，顧客名，対応支店名，機種名，用件が抽出される。

図 10は，97 年 4 月の一ヶ月分のセールスレポートの一覧である。画面上部のフレームにセー ルスレポートのリストが，画面下部のフレームに選択されたセールスレポートの内容が表示さ れる。罒10の例では，リストの 3 番目のレポートを表示している。このレポートにおいて， ○ ×建築が顧客名，若葉台支店が対応支店名，XX282ソフトが機種名，2000 年問題が用件に対応 する。この画面から，例えば， $○$ 建築殿という部分をクリックすることで顧客， $\bigcirc \times$ 建築に 関するレポートを顧客名, 対応支店名, 機種名の視点からブラウズすることができる。 


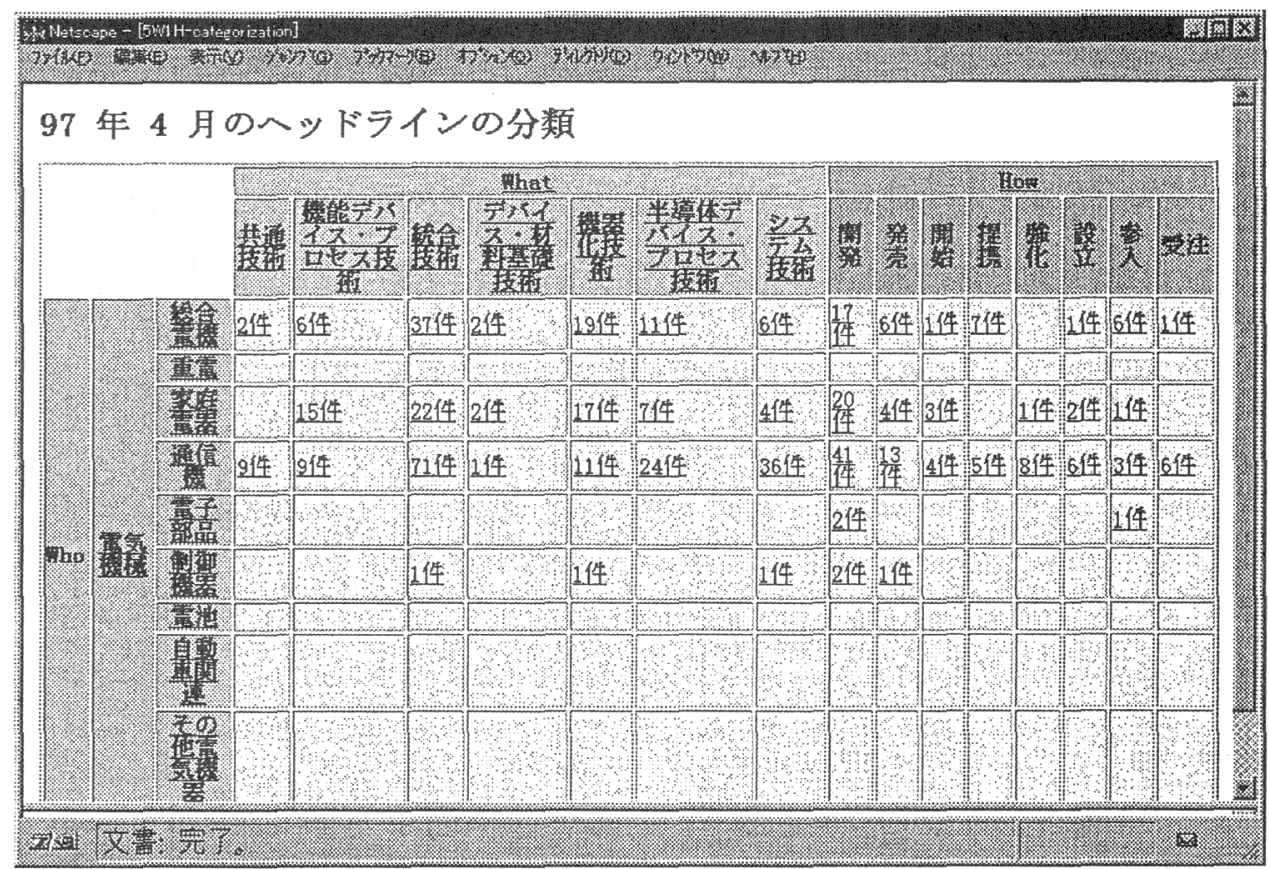

図 9 シソーラスを利用した情報鳥瞰:細分類

顧客名, 対応支店名, 機種名, 用件の中の任意の 2 要素に関して, 情報を共有するレポート からエピソード抄録を生成する。「97/4/16, A 銀行殿が, 新宿営業所に, 空調システムBの保 守対応」という記事をクリックするとレポート本文が表示される。本文には, $44 / 16$ 昨日発生 した空調システム $\mathrm{B}$ の故障の件で $\mathrm{A}$ 銀行殿に報告に伺った。障害対応に関し弊社の対応はま

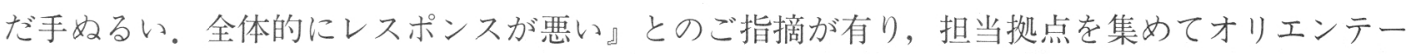
ションを開催する事にした。と記述されている。このレポートに対して, 顧客と機種名をキー

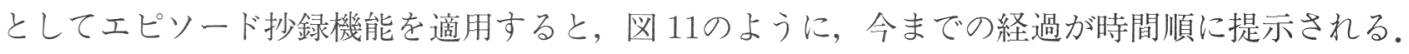
この抄録情報によって，A銀行では空調システム B に障害・保守対応が続発しており，顧客が 不満を持っているというエピソードを読みとることができる。

\section{5 おわりに}

本稿では，5W1H 情報によるエピソード抄録と鳥瞰要約を提案した。これらの機能は，ある 出来事に至るまでの経緯という時間的経過に関する情報要求, 多量の情報の中から主たる話題・ 内容を大局的に把握するという情報要求に応えることを目的としている。エピソード抄録と鳥 


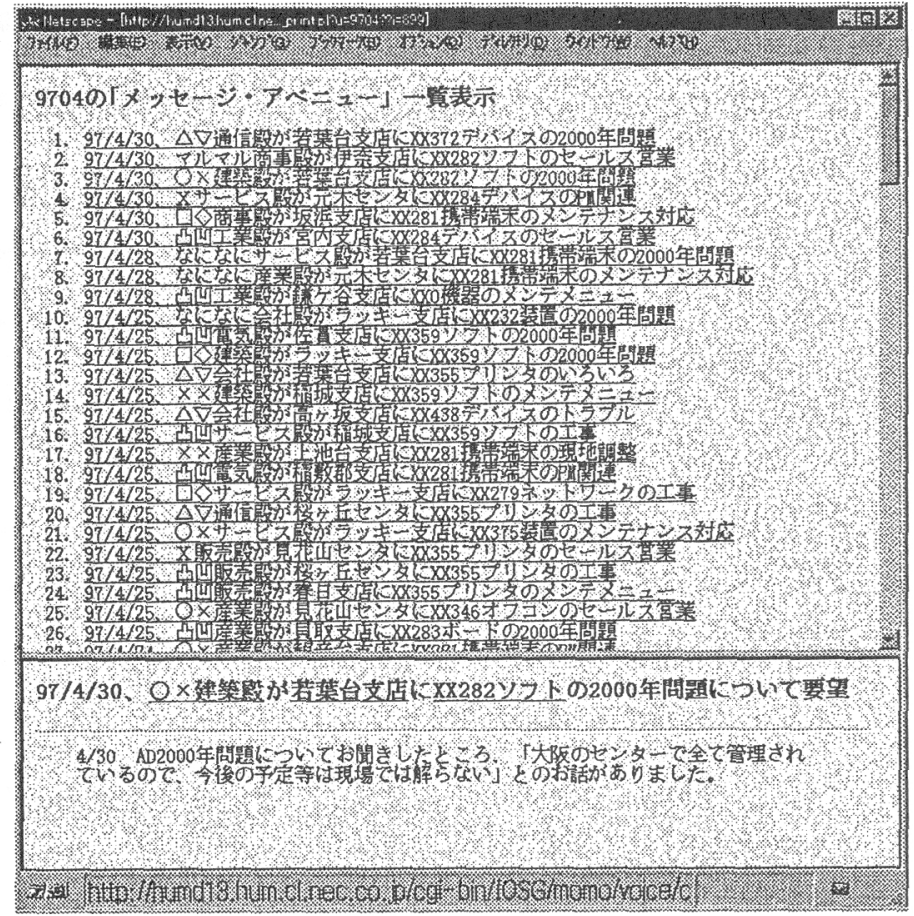

図 10 セールスレポートの一覧

瞰要約を新聞記事 10000 件とセールスレポート 2500 件を対象として適用したところ，エピソー ド抄録は，ユーザの様々な視点から抄録情報をロバス卜に生成できること，鳥瞰要約は，大量に ある情報を大局的に把握するための要約となることを確認した。さらに，鳥瞰要約では，要約率 と要約レベルを定義することができ，ユーザの指定にしたがって要約を生成することができる. 今後, ユーザにとってより満足度の高い抄録・要約機能の実現するため，以下の改良を行なう。

- エピソード抄録:

$5 \mathrm{~W} 1 \mathrm{H}$ の各要素をどの程度共有するものをエピソードとするかに関しては，いくつかの レベルが考えられる(池田，奥村 1998)。ユーザの目的にあわせて，そのレベルをコント ロールして，抄録を生成するべきである。今回，新聞記事では，Who・What・Predicate 要素をキーとしてエピソードを生成し，セールスレポートでは，顧客名，対応支店名，機 種名，用件の中の任意の 2 要素をキーとしてエピソード抄録を生成した。今後は，エピ ソードに関するレベルコントロール機能を実装して評価を行なう(池田，奥村 1998)。ま た，エピソード抄録の構成方法としては，新聞記事への適用のように，本文中に関連情 報を含むへッドラインを列挙する方法と，セールスレポートのように関連情報を含む文 そのもの(ヘッドライン) を列挙する方法を実装したが，長い抄録となる場合もある。同 


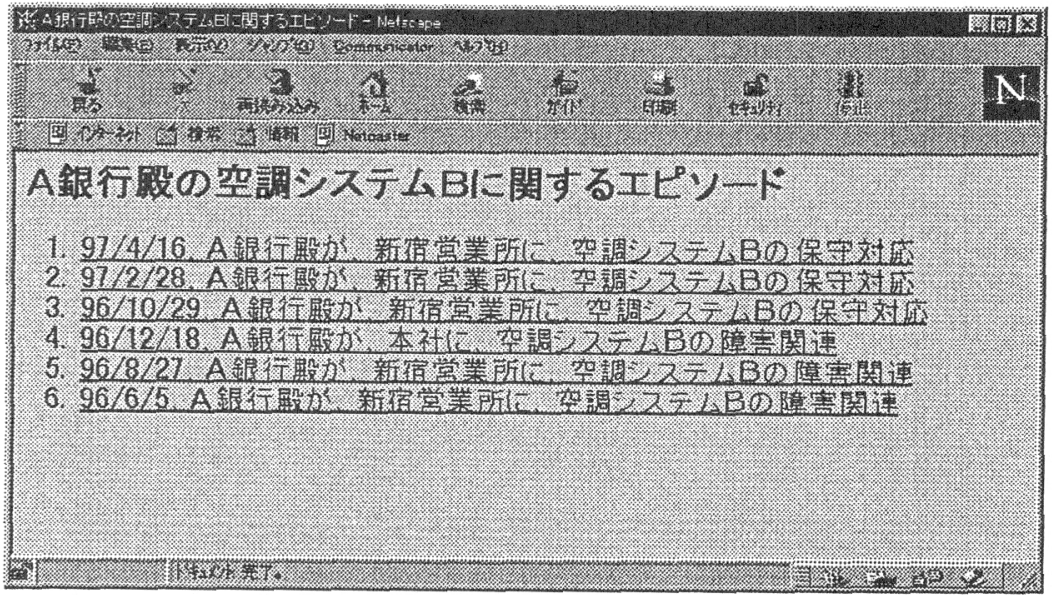

図 11 顧客と機種に関するエピソード

種類の内容のものは繰り返さない，鳥瞰要約と組み合わせて情報を圧縮するなど，簡潔 な抄録を得るための工夫を行なう。

- 鳥瞰要約:

鳥瞰要約では，シソーラスの選択および適用方法が重要である。Who 要素に関しては, 比較的ユニークなシソーラスを構築しやすいが，What 要素はシソーラスは一通りではな く，複合的なオントロジとなる。オントロジを用いていくつかの観点から鳥瞰要約を生 成可能として，ユーザにとって必要な視点の要約を提示する必要がある。また，鳥瞰要 約では，どのようにシソーラスの上位概念を置き換えて要約するのが効果的なのかユー ザの目的によって異なる。要約率，要約レベル，選択するシソーラスを組み合わせてよ り効果的な鳥瞰要約の生成方法を検討する。

\section{参考文献}

安藤真一, 土井伸一 (1994). “新聞記事からの情報抽出システム-指定情報の抽出と多言語文章 による提示-.”人工知能学会第 8 回全国大会, pp. 671-674.

Bates, M. J. (1989). "The Design of Browsing and Berrypicking Techniques for the Online Search Interface." Online Review, 13 (5), 407-424. 
原正巳, 水谷強, 江里口善雄 (1994). “特徵的表現を利用した特許抄録作成法の検討.” 情報処理 学会自然言語処理研究会, NL100-14.

池田崇博, 奥村明俊, 村木一至 (1997). “5W1H 情報を利用する情報分類・ナビゲーション.”人 工知能学会第 11 回全国大会, pp. 370-371.

池田崇博，奥村明俊 (1998). “エピソード検索における適合レベルの調整.”言語処理学会第 4 回年次大会, pp. 116-119.

Ikeda, T., Okumura, A., and Muraki, K. (1998). "Information Classification and Navigation Based on 5W1H of the Target Information." In COLING-ACL'98, pp. 571-577.

McKeown, K. and Radev, R. D. (1995). "Generating summaries of multiple news articles." In SIGIR'95, pp. 74-82.

Mine, T., Aso, K., and Amamiya, M. (1997). "Japanese Document Retrieval System on WWW using Dependency Relations between Words." In Proceedings of PACLING'97 (Pacific Association for Computer Linguistics), pp. 90-215.

奥村明俊, 池田崇博, 村木一至 (1997). “5W1H 分類・ナビゲーションによる情報活用プラット フォーム.”情報処理学会デジタルドキュメント研究会, DD9-1.

Paice, C. D. (1990). "Constructing literature abstracts by computer: Techniques and prospects." Information Processing \& Management, 26 (1), 177-187.

田村俊哉，田村直良 (1992).“文章の表現形式に基づいた要約文章の生成について.”情報処理 学会自然言語処理研究会, NL92-11.

Taylor, R. S. (1968). "Question-Negotiation and Information Seeking in Libraries." College \&6 Research Libraries, 29 (3).

山本和英, 増山繁, 内藤昭三 (1995). “文書内構造を複合的に利用した論説文要約システム GREEN.” 言語処理学会, 2 (1), 39-52.

吉田和宏, 徳永健伸, 田中穂積 (1996). “新聞記事の要約のためのテンプレートの自動抽出.”言 語処理学会第 2 回年次大会, pp. 105-108.

\section{略歴}

奥村 明俊： 1984 年京都大学工学部精密工学科卒業. 1986 年同大学院工学研究 科修士課程修了。同年，NEC 入社．1992 年 10 月南カリフォルニア大学客員 研究員 (DARPA MT プロジェクト 1 年半参加). 1999 年東京工業大学情報

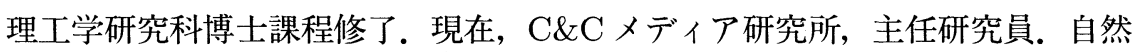
言語処理の研究に従事. 工学博士. 情報処理学会, ヒューマンインタフェー ス学会などの各会員.

池田 崇博: 1994 年東京大学理学部情報科学科卒業. 1996 年同大学院理学系研 究科修士課程修了. 同年, NEC 入社. 現在, C\&Cメディア研究所, 研究員. 
自然言語処理，情報分類の研究に従事. 情報処理学会会員.

村木 一至: 1974 年京都大学工学部情報工学科卒業. 1976 年同大学院工学研究 科修士課程修了. 1979 年 NEC 入社. 現在, パーソナルソフトウェア事業部, グループマネジャ. 自然言語理解, アイディアプロセッシングの研究に従事. 情報処理学会, 人工知能学会, ACL 各会員. Natural Language Engineering 編集委員.

(1998 年 9 月 28 日 受付)

(1998 年 12 月 8 日 再受付)

(1999 年 1 月 14 日採録) 